\title{
Resveratrol attenuates cortical neuron activity: roles of large conductance calcium-activated potassium channels and voltage-gated sodium channels
}

\author{
Ya-Jean Wang ${ }^{1}$, Ming-Huan Chan ${ }^{2,3}$, Linyi Chen ${ }^{4}$, Sheng-Nan Wu ${ }^{5^{*}}$ and Hwei-Hisen Chen ${ }^{1,2,6^{*}}$
}

\begin{abstract}
Background: Resveratrol, a phytoalexin found in grapes and red wine, exhibits diverse pharmacological activities. However, relatively little is known about whether resveratrol modulates the ion channels in cortical neurons. The large-conductance calcium-activated potassium channels ( $\left(\mathrm{BK}_{\mathrm{C}_{\mathrm{a}}}\right)$ and voltage-gated sodium channels were expressed in cortical neurons and play important roles in regulation of neuronal excitability. The present study aimed to determine the effects of resveratrol on $\mathrm{BK}_{\mathrm{Ca}}$ currents and voltage-gated sodium currents in cortical neurons.

Results: Resveratrol concentration-dependently increased the current amplitude and the opening activity of BK $\mathrm{Ca}_{\mathrm{S}}$ channels, but suppressed the amplitude of voltage-gated sodium currents. Similar to the BK $\mathrm{Ca}_{\mathrm{Ca}}$ channel opener NS1619, resveratrol decreased the firing rate of action potentials. In addition, the enhancing effects of BK$_{\mathrm{Ca}_{a}}$ channel blockers tetraethylammonium (TEA) and paxilline on action potential firing were sensitive to resveratrol. Our results indicated that the attenuation of action potential firing rate by resveratrol might be mediated through opening the $\mathrm{BK}_{\mathrm{Ca}}$ channels and closing the voltage-gated sodium channels.

Conclusions: As BK $\mathrm{Ca}_{\mathrm{a}}$ channels and sodium channels are critical molecular determinants for seizure generation, our findings suggest that regulation of these two channels in cortical neurons probably makes a considerable contribution to the antiseizure activity of resveratrol.
\end{abstract}

Keywords: Resveratrol, $\mathrm{BK}_{\mathrm{Ca}}$ channel, Sodium channel, Action potential, Firing rate

\section{Background}

Resveratrol (trans-3,4'5-trihydroxystilbene), a polyphenolic phytoalexin, is derived from some edible materials, including grape skins, peanuts, red wine, and other berries. It has been demonstrated that resveratrol displays diverse pharmacological activities, including anti-platelet [2], anticarcinogenic [4], anti-viral [9, 18, 27] and cardio-protective effects [32, 33, 37, 43, 47]. Moreover, there is accumulating evidence indicating that resveratrol exhibits neuroprotective effects $[8,11,23,28]$. For example, resveratrol attenuates kainic acid-mediated convulsions and the associated

\footnotetext{
* Correspondence: snwu@mail.ncku.edu.tw; hwei@nhri.org.tw

${ }^{5}$ Department of Physiology, National Cheng Kung University Medical College, 1 University Road, Tainan City 70101, Taiwan

${ }^{1}$ Center for Neuropsychiatric Research, National Health Research Institutes,

35, Keyan Road, Zhunan, Miaoli County 35053, Taiwan

Full list of author information is available at the end of the article
}

neurotoxicity $[16,42,49,54]$ and also protects against pentylenetetrazole-induced seizures [31, 40]. Furthermore, resveratrol has the ability to inhibit the electrical activity of neurons [26, 30,50], enabling this compound ideal as a neuroprotective agent against excitatory effects on neurons. This compound can inhibit neuronal discharges in rat hippocampal CA1 area [25] and suppress epileptiform discharges mediated by glutamate [25]. In addition, resveratrol has the ability to produce a dose-dependent inhibition of field excitatory postsynaptic potentials [11]. These effects are likely associated with the alterations in neuronal cell membrane ion channel activities.

In fact, resveratrol has been reported to regulate ion channel activities in a variety of cells. For example, resveratrol inhibits $\mathrm{K}_{\text {ATP }}$ currents [7], $\mathrm{L}$ - and T-type $\mathrm{Ca}^{2+}$ currents and swelling-dependent $\mathrm{Cl}^{-}$currents evoked by 
either hypotonicity or high extracellular glucose-ion conductances in insulin secreting cells [20]. Voltage-gated sodium channels in cardiomyocytes [47] and rat dorsal root ganglion neurons [21] are also blocked by resveratrol. In contrast, resveratrol stimulates $\mathrm{BK}_{\mathrm{Ca}}$ channels in vascular endothelial cells [24] and human cardiac fibroblasts [51].

Despite this, the effects of resveratrol on the membrane properties and the ion channels of neurons have not yet been fully determined. Therefore, the present study examined the effects of resveratrol on $\mathrm{BK}_{\mathrm{Ca}}$ currents and voltage-gated sodium currents by a voltage clamp setup in cortical neurons. Moreover, the effects of resveratrol on action potential firing rate and the $\mathrm{BK}_{\mathrm{Ca}}$ channel inhibitor TEA (or paxilline)-induced hyperexcitability were also evaluated. Our data demonstrated that resveratrol activated $\mathrm{BK}_{\mathrm{Ca}}$ channels, but inhibited voltage-gated sodium currents. Moreover, the action potential firing rates evoked by the depolarizing current and $\mathrm{BK}_{\mathrm{Ca}}$ channel blockers were remarkably decreased by application of resveratrol. These results suggest that alterations of $\mathrm{BK}_{\mathrm{Ca}}$ channel activity and sodium currents by resveratrol may contribute to its reducing effect on action potential firing rates of cortical neurons.

\section{Methods}

\section{Cells preparations}

All experiments were performed in accordance with the Laboratory Animal Center of National Tsing Hua University (NTHU) guidelines for the care and use of animals. Animal use protocols were approved by the NTHU Institutional Animal Care and Use Committee (Approval number 10126). The cerebral cortex was dissected from embryonic day 18 (E18) embryos of Sprague-Dawley rats (purchased from BioLASCO Co., Ltd.). Then, the cells were treated with papain $(10 \mathrm{U} / \mathrm{mL})$. Dissociated cells were washed with PBS three times and re-suspended in minimal essential medium (MEM) supplemented with $5 \%$ HS and $5 \%$ FBS. Cells were seeded onto $30 \mu \mathrm{g} / \mathrm{ml}$ poly-L-lysine-coated coverslips and then cultured in neurobasal medium with B27 (containing additional $25 \mu \mathrm{M}$ glutamate) on DIV (day in vitro) 1. On DIV 3, cells were treated with $5 \mu \mathrm{M}$ cytosine $1-\beta$-D-arabinofuranoside. Half of the neurobasal and glutamine media were replaced by fresh media every 3 days. Glial contamination of neuronal cultures was consistently less than $5 \%$ on DIV7.

The clonal strain, HCN-1A cell line (CRL-10442), originally derived from a cortical tissue removed from a patient undergoing hemispherectomy for intractable seizures, was obtained from the American Type Culture Collection (ATCC). The cells were cultured at $37^{\circ} \mathrm{C}$ in a humidified atmosphere of $5 \% \mathrm{CO}_{2}$ and $95 \%$ air. Culture media (e.g., Dulbecco's Modified Eagle Medium (Life Technologies), were supplemented with $20 \%$ heat- inactivated fetal bovine serum, $1 \% \mathrm{P} / \mathrm{S}$, and $2 \mathrm{mM} \mathrm{L-}$ glutamine (Life Technologies) [52].

\section{Chemicals and solutions}

Resveratrol (purity $\geq 99 \%$ ), NS1619 (purity $\geq 99 \%$ ), tetrodotoxin (TTX) (purity $\geq 98 \%$ ), tetraethylammonium chloride (TEA) (purity $\geq 98 \%$ ), paxilline, a mycotoxin of penicillium origin (purity $\geq 98 \%$ ), and papain (purity $\geq 99 \%$ ) were purchased from Sigma-Aldrich. Resveratrol and NS1619 were dissolved in dimethylsulfoxide (DMSO). TTX was dissolved in water. All culture media, FBS, HS, L-glutamate, trypsin/ EDTA, and penicillin-streptomycin were purchased from Invitrogen. The composition of normal Tyrode's solution was as follows (in $\mathrm{mM}$ ): $\mathrm{NaCl} 136.5, \mathrm{KCl} 5.4, \mathrm{CaCl}_{2} 1.8$, $\mathrm{MgCl}_{2}$ 0.53, glucose 5.5, and HEPES 5.5 (pH 7.4). To record $\mathrm{BK}_{\mathrm{Ca}}$ currents and action potentials, the patch pipettes were filled with a solution (in $\mathrm{mM}$ ): $\mathrm{KCl} 145, \mathrm{MgCl}_{2} 1$, $\mathrm{Na}_{2}$ ATP 3, EGTA 0.1, and HEPES 5.5 (pH 7.2). To measure $I_{\mathrm{Na}}$, potassium ions inside the pipette solution were replaced with equimolar $\mathrm{Cs}^{+}$ions ( $\mathrm{pH}$ 7.2). In single-channel current recordings of $\mathrm{BK}_{\mathrm{Ca}}$ channels, the high $\mathrm{K}^{+}$-bathing solution contained (in $\mathrm{mM}$ ): $\mathrm{KCl} 145, \mathrm{MgCl}_{2} 0.53, \mathrm{CaCl}_{2}$ 1.8, and HEPES 5 (pH 7.4). The pipette solution contained $(\mathrm{mM}): \mathrm{KCl} 145, \mathrm{MgCl}_{2} 2$, and HEPES 5 (pH 7.2).

\section{Electrophysiological recordings and data analysis}

Membrane currents and action potentials of primary embryonic rat cortical neurons were recorded in the whole-cell configuration of the patch-clamp technique using patch pipettes with a tip resistance of 3-6 $\mathrm{M} \Omega$, unless mentioned otherwise. All analog signals were filtered at 1 or $3 \mathrm{kHz}$ before digitization at 10 or $50 \mathrm{kHz}$ and stored on a hard disk using a PC-compatible computer. All data analysis was performed with Clampfit software (Molecular Devices). The EPC-10 amplifier was used for voltage-clamp recording and current-clamp recording $[36,56]$. The signals recorded from human cortical $(\mathrm{HCN}-1 \mathrm{~A})$ neurons were stored in a Slimnote $\mathrm{VX}_{3}$ computer (Lemel) via a universal serial bus port at $10 \mathrm{kHz}$ through a Digidata 1322A interface (Molecular Devices). This device was controlled by the pCLAMP 9.0 software (Molecular Devices). The signals were lowpass filtered at 1 to $3 \mathrm{kHz}$. Ion currents recorded during cell-attached recordings were stored and analyzed using the pCLAMP 9.0 software (Molecular Devices), the Origin 7.5 software (Microcal Software, Inc), the SigmaPlot 7.0 software (SPSS, Inc), or custom-made macros in Excel 2003 (Microsoft).

The PatchMaster-generated voltage-step protocols were employed to investigate the current-voltage ( $I-V)$ relations for ion currents in embryonic rat cortical neurons. To calculate percentage inhibition of resveratrol on $I_{\mathrm{Na}}$, the cells were depolarized from a holding potential of $-80 \mathrm{mV}$, and a 50 -msec depolarizing pulse to $-20 \mathrm{mV}$. The amplitude 
of $I_{\mathrm{Na}}$ obtained at the level of $-20 \mathrm{mV}$ was then compared after addition of the different concentrations $(5-40 \mu \mathrm{M})$ of resveratrol. The amplitude of $I_{\mathrm{Na}}$ in the presence of $0.1 \%$ DMSO was taken as $100 \%$. Then, those exposed to different concentrations of resveratrol were then compared. In these experiments, the TTX was taken as a positive control. The $\mathrm{BK}_{\mathrm{Ca}}$ channel currents in response to resveratrol were examined in the condition of the extracellular solution containing TEA $(1 \mathrm{mM})$, a $\mathrm{BK}_{\mathrm{Ca}}$ channel blocker, to block $\mathrm{BK}_{\mathrm{Ca}}$ channel currents. The net currents subtracted before and after treatment with $\mathrm{BK}_{\mathrm{Ca}}$ channel blockers were defined as $\mathrm{BK}_{\mathrm{Ca}}$ channel currents. For these experiments, the cells were depolarized from -50 to $+70 \mathrm{mV}$. The amplitude of potassium outward current was measured at the end of the depolarizing pulses. The NS1619, a BK $\mathrm{Ca}$ channel activator, was taken as a positive control. In single-channel recordings, open probability $\left(\mathrm{N} \cdot \mathrm{P}_{\mathrm{o}}\right)$ and single-channel conductance for $\mathrm{BK}_{\mathrm{Ca}}$ channels were determined by all-point amplitude histograms. Open lifetime distributions were fitted with logarithmically scaled bin width. In cell-attached configuration, the relationships between membrane potentials and the probability of channel openings were fitted with a Boltzmann function of the form: $N \cdot P_{o}=n_{P} /\left\{1+\exp \left[-\left(V-V_{1 / 2}\right) / k\right]\right\}$ where $n_{P}$ is the maximal open probability, $V$ is the membrane potential in $\mathrm{mV}, \mathrm{V}_{1 / 2}$ is the voltage at which there is half-maximal activation, $\mathrm{k}$ is the slope factor of the activation curve.

\section{Statistical analysis}

Results were expressed as mean \pm standard error $(n=$ number of patches or cells). The significance of differences between means was tested with paired $t$-test and differences were considered significant at $P<0.05$.

\section{Results and Discussion}

The large conductance $\mathrm{Ca}^{2+}$-activated $\mathrm{K}^{+}\left(\mathrm{BK}_{\mathrm{Ca}}\right)$ channel currents in response to resveratrol were examined in the condition of the intracellular dialysis with solution containing EGTA $0.15 \mathrm{mM}$ and the extracellular solution containing $\mathrm{CaCl}_{2} 1.8 \mathrm{mM}$. The potassium outward currents were elicited by $300 \mathrm{~ms}$ depolarization of membrane potential to $+70 \mathrm{mV}$ from holding potential $-50 \mathrm{mV}$. To evaluate whether resveratrol could affect the $\mathrm{BK}_{\mathrm{Ca}}$ currents in cortical neurons, the effects of resveratrol on the current amplitude were examined in the presence of TEA, a $\mathrm{BK}_{\mathrm{Ca}}$ channel blocker. The net response subtracted before and after treatment with TEA, was defined as $\mathrm{BK}_{\mathrm{Ca}}$ channel current. A putative $\mathrm{BK}_{\mathrm{Ca}}$ channel activator NS1619 was used as a positive control. The current difference between application of TEA, combination of NS1619 and TEA (Fig. 1a), or combination of resveratrol and TEA (Fig. 1b-d) in the same cell was the component of activated $\mathrm{BK}_{\mathrm{Ca}}$ currents. TEA-sensitive $\mathrm{K}_{\mathrm{Ca}}$ currents recorded at $+70 \mathrm{mV}$ were not significantly altered after exposure to resveratrol at $10 \mu \mathrm{M}$ (Fig. 1b), whereas higher concentrations of resveratrol (20 and $40 \mu \mathrm{M})$ enhanced TEAsensitive $\mathrm{K}_{\mathrm{Ca}}$ currents. The peak outward currents recorded at $+70 \mathrm{mV}$ before and after exposure to resveratrol $(20 \mu \mathrm{M})$ were $139 \pm 18 \mathrm{pA}$ and $230 \pm 6 \mathrm{pA}(n=3)$, respectively (Fig. 1c). Resveratrol $(40 \mu \mathrm{M})$ further enhanced TEAsensitive $\mathrm{K}_{\mathrm{Ca}}$ currents. The peak outward currents recorded at $+70 \mathrm{mV}$ were $254 \pm 12 \mathrm{pA}$ and $622 \pm 13 \mathrm{pA}(n=3)$, respectively (Fig. 1d).

The $\mathrm{BK}_{\mathrm{Ca}}$ channels are both voltage-gated and intracellular $\mathrm{Ca}^{2+}$ dependent [41], which are sensitive to TEA or paxilline [38]. When activated by cell membrane depolarization and elevation of intracellular $\mathrm{Ca}^{2+}$ concentration, $\mathrm{BK}_{\mathrm{Ca}}$ channels allow the efflux of $\mathrm{K}^{+}$out of the cell, thus repolarizing and hyperpolarizing the membrane potential. This turns off voltage-dependent $\mathrm{Ca}^{2+}$ channels and thus inhibits the influx of $\mathrm{Ca}^{2+}$ into the cell. These negative feedback mechanisms allow $\mathrm{BK}_{\mathrm{Ca}}$ channels to play an important role in regulating firing properties. $\mathrm{BK}_{\mathrm{Ca}}$ channels are expressed in various brain neurons where they play important roles in regulating action potential duration, firing frequency and neurotransmitter release [34]. The present study revealed that resveratrol enhanced TEA-sensitive potassium currents, suggesting that it is capable of stimulating $\mathrm{BK}_{\mathrm{Ca}}$ currents in cortical neurons.

To further elucidate the effect of resveratrol on the activity of $\mathrm{BK}_{\mathrm{Ca}}$ channels, the single-channel recording with a cell-attached configuration was performed in human cortical neurons. These studies were performed in symmetrical $\mathrm{K}^{+}(145 \mathrm{mM})$ concentration and the bath solution contained $1.8 \mathrm{mM} \mathrm{Ca}^{2+}$. The cells were held at $+60 \mathrm{mV}$. As shown in Fig. 2a, when resveratrol $(10 \mu \mathrm{M})$ was applied to the chamber, the activity of channel openings was significantly increased. However, no change in single-channel amplitude was demonstrated in the presence of resveratrol. These findings suggested that its binding site should not be located in the pore region of the $\mathrm{BK}_{\mathrm{Ca}}$ channels. In addition, resveratrolinduced changes in the probability of channel openings were reversed by a $\mathrm{BK}_{\mathrm{Ca}}$ channel blocker paxilline $(1 \mu \mathrm{M})$ (Fig. 2b), revealing that the components affected by resveratrol are mediated by its action on $\mathrm{BK}_{\mathrm{Ca}}$ channels.

Sodium currents were evoked by a depolarizing pulse to $-20 \mathrm{mV}$ from a holding potential of $-80 \mathrm{mV}$. Being a positive control, TTX, a voltage-gated sodium channel blocker, significantly reduced sodium current amplitude (Fig. 3a). Resveratrol (10 and $20 \mu \mathrm{M})$ significantly decreased sodium current amplitude at the level of $-20 \mathrm{mV}$ within $5 \mathrm{~min}$, whereas resveratrol $(5 \mu \mathrm{M})$ did not affect the amplitude of sodium currents (Fig. 3b). To calculate the percentage inhibition of resveratrol on 

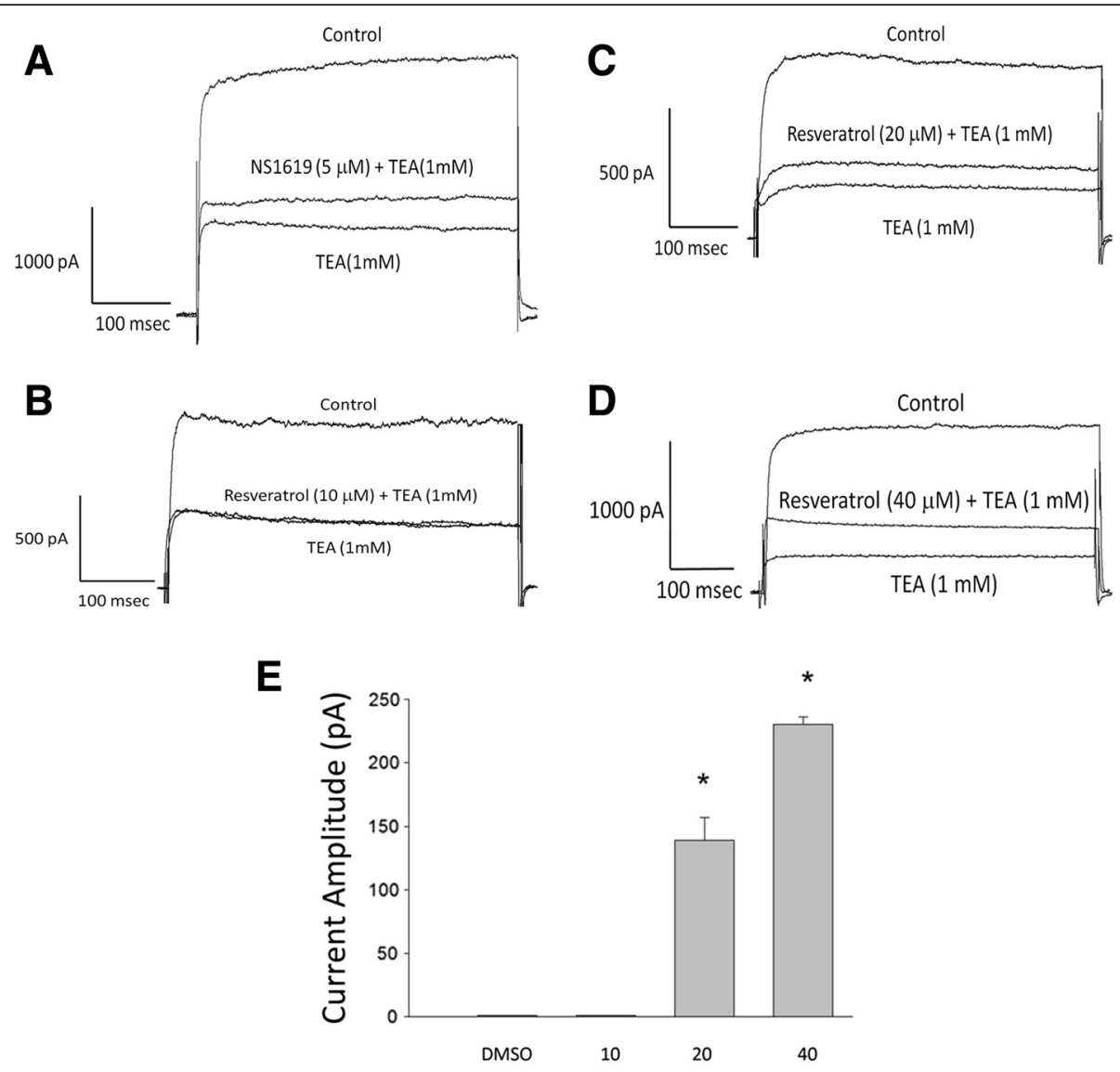

Resveratrol $(\mu \mathrm{M})$

Fig. 1 Stimulatory effect of resveratrol on TEA-sensitive potassium currents in embryonic rat cortical neurons. The whole-cell recording was conducted in these experiments. Because $B K_{C_{a}}$ channels are typically blocked by externally applied tetraethylammonium (TEA, $1 \mathrm{mM}$ ), this compound is often used to determine the contribution of BK $\mathrm{Ca}_{\mathrm{a}}$ channels to the whole-cell currents. All cells were held at $-50 \mathrm{mV}$ in Tyrode's solution containing $1.8 \mathrm{mM}$ $\mathrm{CaCl}_{2}$. Then, cells were depolarized from -50 to $+70 \mathrm{mV}$ with a duration of $300 \mathrm{msec}$. a The currents were recorded in the presence of TEA (1 mM) combined with NS1619 (5 $\mu \mathrm{M})$ from the same cell. b, c, d Original current traces are representative of 3 experiments. The currents were recorded in the presence of TEA (1 mM) or TEA $(1 \mathrm{mM})$ combined with resveratrol $(10,20$ and $40 \mu \mathrm{M})$ from the same cell. Resveratrol $(20$ and $40 \mu \mathrm{M}$, but not $10 \mu \mathrm{M})$ increased the TEA-sensitive current in these cells $(n=3)$. e Bar graph showing the effect of resveratrol on TEA-induced currents. Each bar indicates the mean \pm SEM. $(n=3){ }^{*}$ Significantly different from control $(P<0.01)$

sodium currents, the cells were depolarized from -80 to $-20 \mathrm{mV}$ with a duration of $50 \mathrm{~ms}$ and the peak amplitude of sodium inward currents was measured. The amplitude of sodium currents in the control condition was taken as $100 \%$ and those exposed to different concentrations of resveratrol were then compared. Fig. 3c illustrated that resveratrol $(5-20 \mu \mathrm{M})$ reduced the amplitude of sodium currents in a concentration-dependent manner.

In fact, the TTX-S sodium currents and $\mathrm{BK}_{\mathrm{Ca}}$ currents are important in shaping the action potential of neurons $[3,13]$. The effects of resveratrol on cellular excitability were examined in rat cortical neurons with repetitive firings evoked by positive current injection. For the measurement of evoked action potential firings in currentclamp, the membrane potentials were held at $-60 \mathrm{mV}$.
During a $6 \mathrm{~s}$ injection of a positive current (ranging from 5 to $30 \mathrm{pA}$ ), repetitive firings could be evoked in these cells. The frequency $(\mathrm{Hz})$ of action potential firings was determined by dividing the number of action potentials by the duration of the recording period. Resveratrol $(20 \mu \mathrm{M})$ was applied into the chamber for $2 \mathrm{~min}$ and reduced the action potential firing frequency from the control value of $6.9 \pm 0.3 \mathrm{~Hz}$ to $0.4 \pm 0.2 \mathrm{~Hz} \quad(n=8)$ (Fig. 4a). Similarly, when the cells were treated with TTX, a specific sodium channel blocker, or $\mathrm{BK}_{\mathrm{Ca}}$ channel activator NS1619 $(5 \mu \mathrm{M})$, the frequency of action potentials was significantly decreased in embryonic rat cortical neurons (Fig. 4b, c).

The effects of resveratrol on action potential firings were also examined in the presence of two $\mathrm{BK}_{\mathrm{Ca}}$ channel blockers, TEA or paxilline, to evaluate whether resveratrol 
A
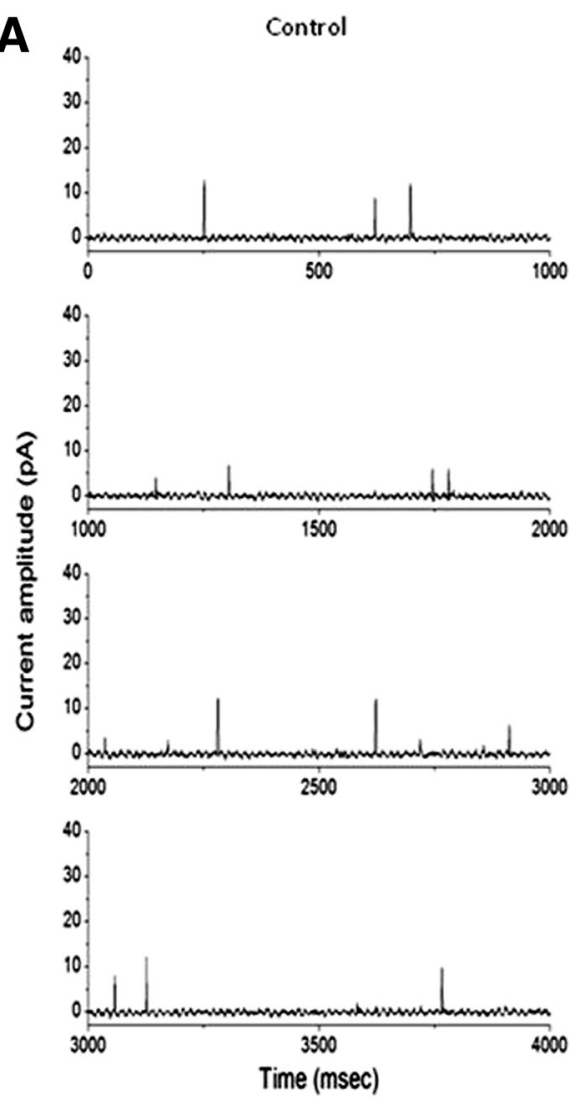

B

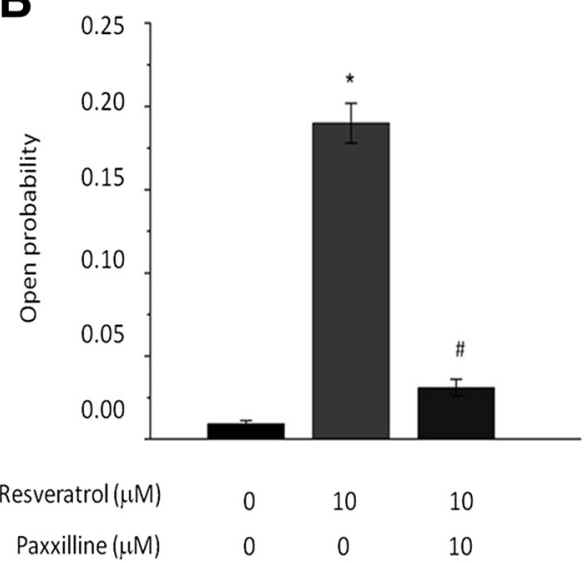

Resveratrol $(10 \mu \mathrm{M})$
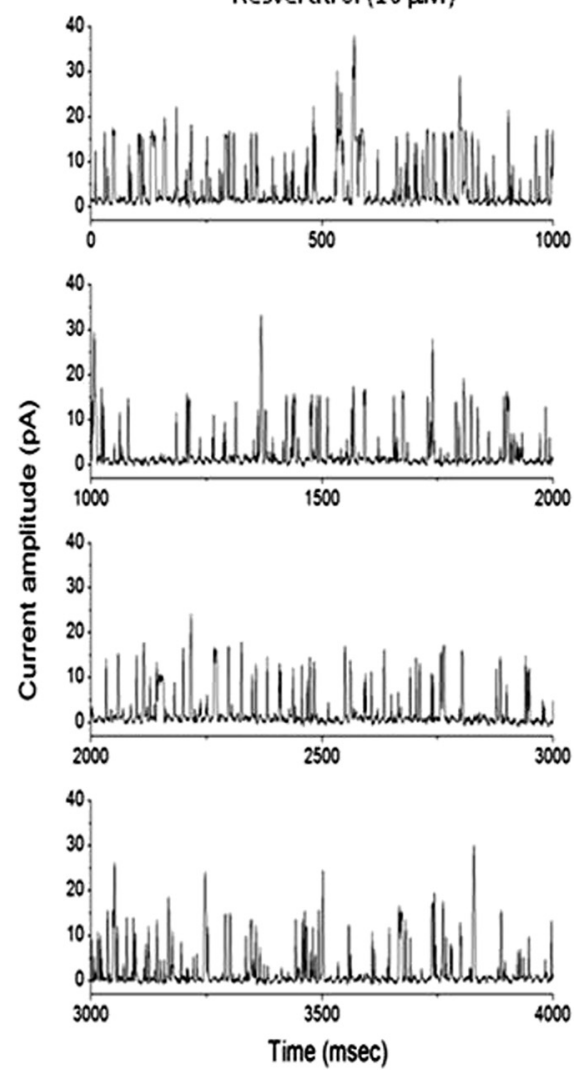

Fig. 2 Resveratrol evoked the $B K_{C_{a}}$ channel responses in human cortical $(\mathrm{HCN}-1 \mathrm{~A})$ neurons. In these experiments, cells were bathed in high-K ${ }^{+}$ solution and cell-attached current recordings were made. The holding potential was constantly set at $+60 \mathrm{mV}$. a Original current trace obtained in the absence (left) and presence (right) of $10 \mu \mathrm{M}$ resveratrol. Resveratrol was applied to the bath solution. The upward deflection indicates the opening events of the channels. $\mathbf{b}$ Bar graph showing the effect of resveratrol and resveratrol plus paxilline on the open probability of $B K_{C a}$ channels. Each bar indicates the mean \pm SEM $(n=7-9)$. Res: $10 \mu \mathrm{M}$ resveratrol; Pax: $1 \mu \mathrm{M}$ paxilline. " Significantly different from control $(P<0.05)$. "Significantly different from resveratrol alone group $(P<0.01)$

could suppress the increased excitability of cortical neurons evoked by inhibition of $\mathrm{BK}_{\mathrm{Ca}}$ channels. As shown in Fig. 5a, application of TEA increased the action potential firing rate from the control value of $3.5 \pm 0.3$ to $5.7 \pm$ $0.7 \mathrm{~Hz}$. In the presence of $20 \mu \mathrm{M}$ resveratrol combined with TEA, the increase in firing rate evoked by TEA was reduced to $0.1 \pm 0.1 \mathrm{~Hz}$. In addition, when the cells were treated with paxilline, the action potential firing rate was also increased. After applications of resveratrol combined with paxilline, the increase in firing rate evoked by paxilline was significantly reduced (Fig. 5b). These results suggest that $\mathrm{BK}_{\mathrm{Ca}}$ channel opening and sodium channel 


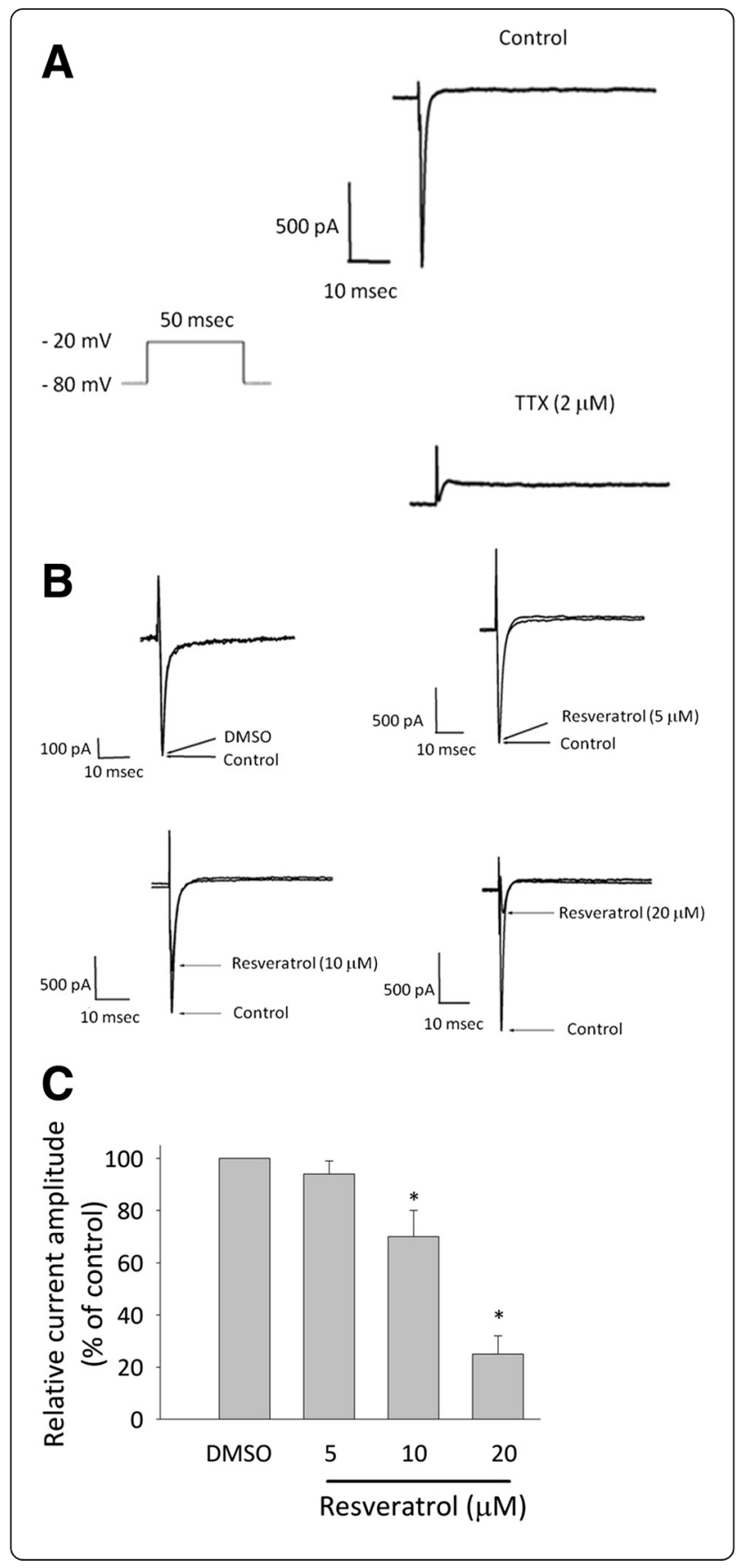

inhibition by resveratrol could underlie, at least in part, the inhibition of action potential firing in the cortical neurons.

Resveratrol has been reported to stimulate $\mathrm{BK}_{\mathrm{Ca}}$ currents in human vascular endothelial cells and human cardiac fibroblasts [24, 51], which might be associated with its cardioprotective effect. The present study demonstrated that resveratrol could stimulate the activities of $\mathrm{BK}_{\mathrm{Ca}}$ channels in cortical neurons. In fact, $\mathrm{BK}_{\mathrm{Ca}}$ channel is considered to be one of the intrinsic molecular determinants for the control of neuronal excitability in the central nervous system
Fig. 3 Concentration-dependent effect of resveratrol on voltage-gated sodium currents. The cells were bathed in $\mathrm{Ca}^{2+}$-free, Tyrode's solution. a Functional expression of the voltage-gated sodium current in embryonic rat cortical neurons. Superimposed current traces in control (top panel) and during exposure to $2 \mu \mathrm{M}$ TTX (lower panel). Under the experimental condition, depolarizing voltage command from a holding potential of $-80 \mathrm{mV}$ elicited an inward current sensitive to TTX. This inward $\mathrm{Na}^{+}$ current was maximally activated by a test pulse at $-20 \mathrm{mV}(n=8)$. b Concentration dependent effects of resveratrol on inward $\mathrm{Na}^{+}$currents. The currents were evoked depolarizing the cells from a holding potential of $-80 \mathrm{mV}$ to $-20 \mathrm{mV}$. Representative traces showing the depression of inward $\mathrm{Na}^{+}$currents by resveratrol at different concentrations in these cells. c The graph shows the concentration dependent effect of resveratrol on the amplitudes of the inward currents measured at the peaks $(n=3-5)$. * Significantly different from control group $(P<0.05)$

and play a role in the etiology of some neurological diseases. Recent studies have demonstrated the implication of $\mathrm{BK}_{\mathrm{Ca}}$ channels in Fragile X Syndrome (FXS) pathology [22]. In fact, a selective $\mathrm{BK}_{\mathrm{Ca}}$ channel opener molecule (BMS-204352) rescues a broad spectrum of behavioral impairments (social, emotional and cognitive) in an animal model of FXS [17]. Resveratrol might be also beneficial to patients with FXS.

$\mathrm{BK}_{\mathrm{Ca}}$ channels also play an important role in seizure etiology. Loss-of-function $\mathrm{BK}_{\mathrm{Ca}}$ channel mutations can lead to temporal lobe epilepsy, tonic-clonic seizures and alcohol withdrawal seizures [34, 35]. Paradoxically, some mutations in $\mathrm{BK}_{\mathrm{Ca}}$ channel subunit can give rise to channel gain-of-function that leads to development of idiopathic epilepsy (primarily absence epilepsy) [34]. Thus, both loss-of-function and gain-of-function $\mathrm{BK}_{\mathrm{Ca}}$ channels might serve as molecular targets for drugs to suppress certain seizure phenotypes including temporal lobe seizures and absence seizures, respectively. Actually, resveratrol has been found to reduce the kainateinduced temporal lobe epilepsy [16, 54], suggesting that resveratrol might have potential for treatment of this seizure type through activation of $\mathrm{BK}_{\mathrm{Ca}}$ channels.

There are nine recognized members of the voltagegated sodium channel family $\left(\mathrm{Na}_{\mathrm{v}} 1.1-\mathrm{Na}_{\mathrm{v}} 1.9\right)$. Of these, $\mathrm{Na}_{\mathrm{v}} 1.1, \mathrm{Na}_{\mathrm{v}} 1.2, \mathrm{Na}_{\mathrm{v}} 1.3$ and $\mathrm{Na}_{\mathrm{v}} 1.6$ are highly expressed in the central nervous system [10]. In particular, the $\mathrm{Na}_{\mathrm{v}} 1.1, \quad \mathrm{Na}_{\mathrm{v}} 1.2$ and $\mathrm{Na}_{\mathrm{v}} 1.6$ sodium channels are expressed in cortical tissue [55], which are all TTXsensitive [5]. Consistently, we found that the sodium currents recorded in the rat cortical neurons are totally blocked by TTX. It appears that $\mathrm{Na}_{\mathrm{v}} 1.1, \mathrm{Na}_{\mathrm{v}} 1.2$ and $\mathrm{Na}_{\mathrm{v}} 1.6$ sodium channels should be the targets for resveratrol.

It has been shown that resveratrol suppresses the TTX-S sodium currents in rat dorsal root ganglion neurons [21] that plays an important role in pain transmission $[1,53]$. Inhibition of sodium currents by resveratrol may account for its analgesic effects [12, 14, 44]. The 


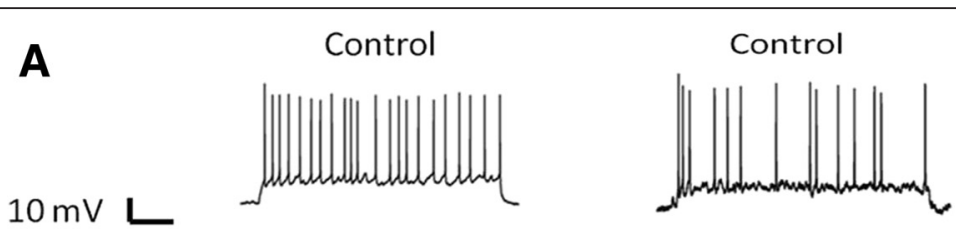

$1 \mathrm{~S}$

Resveratrol $(20 \mu \mathrm{M})$

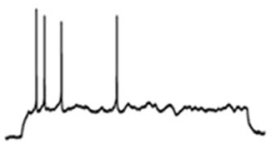

$\operatorname{TTX}(2 \mu \mathrm{M})$

Control

C Control
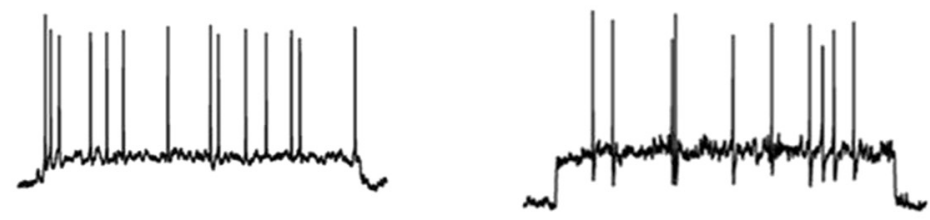

$\operatorname{TTX}(2 \mu \mathrm{M})$
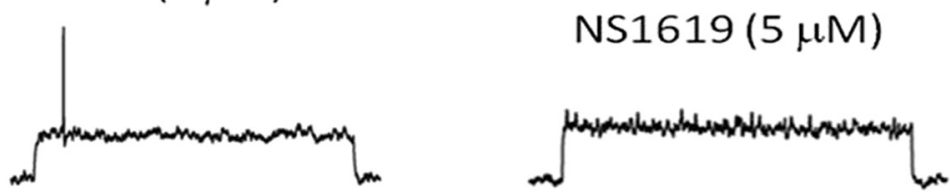

Fig. 4 Resveratrol reduced action potential firing in embryonic rat cortical neuron. Current-clamp configuration was made in these experiments. All cells were bathed in Tyrode's solution containing $1.8 \mathrm{mM} \mathrm{CaCl}_{2}$. Trains of action potentials were evoked by a depolarizing current step. a Original potential traces obtained in control (upper) and in the presence (lower) of resveratrol ( $20 \mu \mathrm{M}$ ) by injecting a threshold current. b The potential traces obtained in the absence and presence of TTX $(2 \mu \mathrm{M})$. c The potential traces obtained in the absence and presence of NS1619 (5 $\mu \mathrm{M})$. In the presence of resveratrol, TXX, and NS1619, the action potential firing frequency was significantly decreased

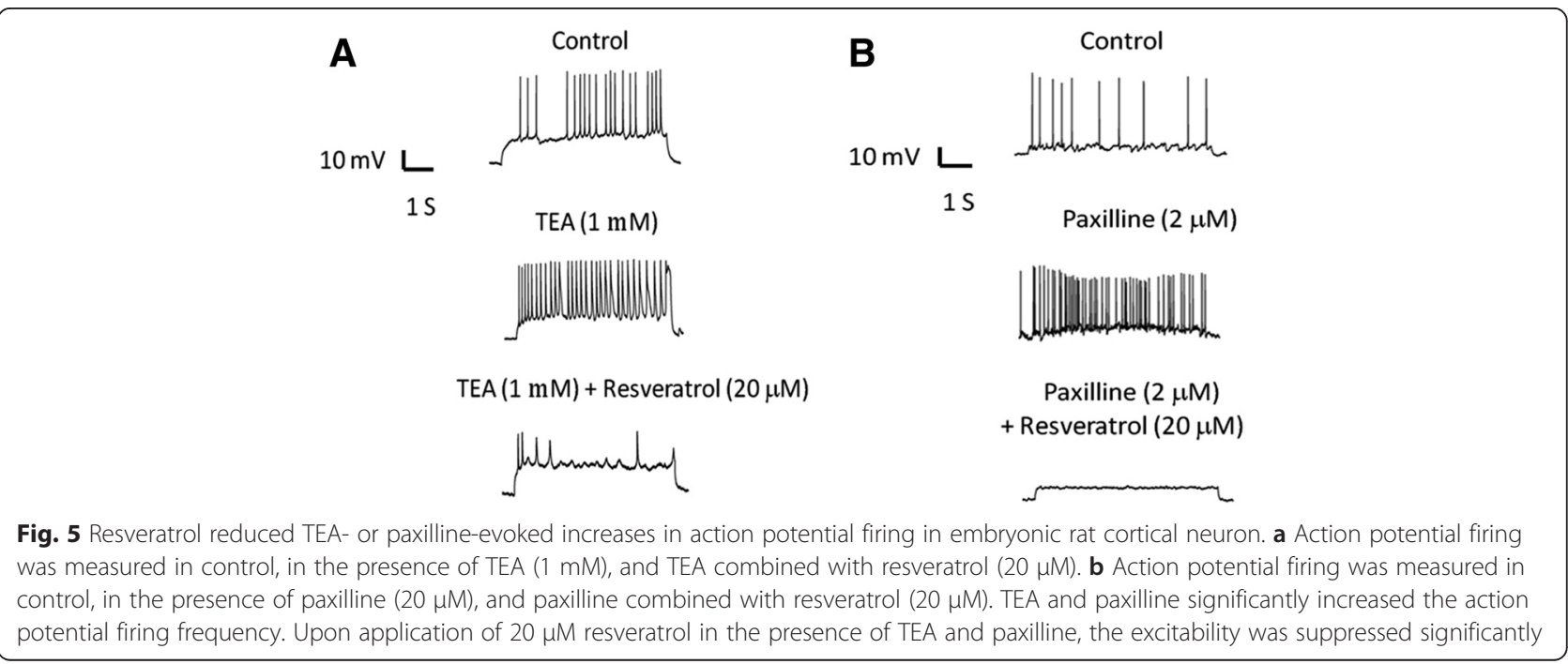


present study demonstrated that resveratrol can inhibit the TTX-S sodium currents in rat cortical neurons. Several lines of evidence revealed that the pathophysiology of both acquired and inherited epilepsy is associated with abnormal expression or function of voltage-gate sodium currents [29]. The $\mathrm{Na}_{\mathrm{v}} 1.1$ or $\mathrm{Na}_{\mathrm{v}} 1.2$ mutations are associated with generalized epilepsy and inherited epilepsy [6, 19]. Together with the observations that the protective effects of resveratrol against seizure activities caused by kainic acid or pentylenetetrazole $[16,45,46,48]$, our findings suggest that in addition to activation of $\mathrm{BK}_{\mathrm{Ca}}$ channels, blockade of voltage-gated sodium channels in the cortical neurons might also contribute to the anti-seizure effects of resveratrol.

\section{Conclusions}

In summary, our results suggested that the suppressing effect of resveratrol on action potential firing rate may be mediated by opening $\mathrm{BK}_{\mathrm{Ca}}$ channels and closing voltage-gated sodium channels. Current clinical available anti-epileptics are mostly sodium channel blockers. The sodium channel blockers were very effective for treating generalized epilepsy with febrile seizures plus, while it aggravates symptoms in patients with severe myoclonic epilepsy of infancy $[15,39]$. With dual effects on $\mathrm{BK}_{\mathrm{Ca}}$ and sodium channels, resveratrol might have the potential as a broad-spectrum anti-seizure medication.

\section{Abbreviations}

$\mathrm{BK}_{\mathrm{Ca}}$ : large-conductance calcium-activated potassium channel; HCN-

$1 \mathrm{~A}$ : human cortical neuron; $I_{\mathrm{Na}}$ : sodium current; TEA: tetraethylammonium; TTX: tetrodotoxin

\section{Competing interests}

The authors declare that they have no competing interest.

\section{Authors' contributions}

YJW, SNU, and HHC conceived the study; YJW, SNU, and MHC are responsible for experimental design; LC: participated in the cell isolation and culture; YJW and SNU performed electrophysiology experiments and data analysis, YJW prepared the figures and drafted the manuscript; MHC, SNU and HHC edited the manuscript. All authors read and approved the final manuscript.

\section{Acknowledgments}

This work was supported by a grant (NP-103-PP-02) from the National Health Research Institutes, Taiwan.

\section{Author details \\ ${ }^{1}$ Center for Neuropsychiatric Research, National Health Research Institutes, 35, Keyan Road, Zhunan, Miaoli County 35053, Taiwan. ${ }^{2}$ Institute of Neuroscience, National Chengchi University, 64, Sec.2, ZhiNan Road, Wenshan District, Taipei City 11605, Taiwan. ${ }^{3}$ Research Center for Mind, Brain, and Learning, National Chengchi University, 64, Sec.2, ZhiNan Road, Wenshan District, Taipei City 11605, Taiwan. ${ }^{4}$ Institute of Molecular Medicine, National Tsing Hua University, 101, Section 2, Kuang-Fu Road, Hsinchu 30013, Taiwan. ${ }^{5}$ Department of Physiology, National Cheng Kung University Medical College, 1 University Road, Tainan City 70101, Taiwan. ${ }^{6}$ Department of Pharmacology and Toxicology, School of Medicine, Tzu Chi University, 701, Section 3, Chung-Yang Road, Hualien 97004, Taiwan.}

Received: 17 November 2015 Accepted: 6 May 2016 Published online: 21 May 2016

\section{References}

1. Baker MD, Wood JN. Involvement of $\mathrm{Na}+$ channels in pain pathways. Trends Pharmacol Sci. 2001;22(1):27-31.

2. Bertelli AA, Giovannini L, Giannessi D, Migliori M, Bernini W, Fregoni M, Bertelli A. Antiplatelet activity of synthetic and natural resveratrol in red wine. Int J Tissue React. 1995;17(1):1-3.

3. Blair NT, Bean BP. Roles of tetrodotoxin (TTX)-sensitive Na + current, TTXresistant $\mathrm{Na}+$ current, and $\mathrm{Ca} 2+$ current in the action potentials of nociceptive sensory neurons. J Neurosci. 2002;22(23):10277-90.

4. Cal C, Garban H, Jazirehi A, Yeh C, Mizutani Y, Bonavida B. Resveratrol and cancer: chemoprevention, apoptosis, and chemo-immunosensitizing activities. Curr Med Chem Anticancer Agents. 2003;3(2):77-93.

5. Catterall WA, Goldin AL, Waxman SG. International Union of Pharmacology. XLVII. Nomenclature and structure-function relationships of voltage-gated sodium channels. Pharmacol Rev. 2005:57(4):397-409.

6. Catterall WA, Kalume F, Oakley JC. NaV1.1 channels and epilepsy. J Physiol. 2010:588(Pt 11):1849-59.

7. Chen WP, Chi TC, Chuang LM, Su MJ. Resveratrol enhances insulin secretion by blocking K(ATP) and K(V) channels of beta cells. Eur J Pharmacol. 2007; 568(1-3):269-77.

8. Curro M, Trovato-Salinaro A, Gugliandolo A, Koverech G, Lodato F, Caccamo D, Calabrese V. lentile R. Resveratrol protects against homocysteine-induced cell damage via cell stress response in neuroblastoma cells. J Neurosci Res. 2014; 93(1):149-56. doi:10.1002/jnr.23453.

9. Docherty JJ, Fu MM, Stiffler BS, Limperos RJ, Pokabla CM, DeLucia AL. Resveratrol inhibition of herpes simplex virus replication. Antiviral Res. 1999:43(3):145-55.

10. Eijkelkamp N, Linley JE, Baker MD, Minett MS, Cregg R, Werdehausen R, Rugiero F. Wood J.N. Neurological perspectives on voltage-gated sodium channels. Brain. 2012;135(Pt 9):2585-612.

11. Gao ZB, Chen $X Q$, Hu GY. Inhibition of excitatory synaptic transmission by trans-resveratrol in rat hippocampus. Brain Res. 2006;1111(1):41-7.

12. Gentilli M, Mazoit JX, Bouaziz H, Fletcher D, Casper RF, Benhamou D, Savouret JF. Resveratrol decreases hyperalgesia induced by carrageenan in the rat hind paw. Life Sci. 2001;68(11):1317-21.

13. Golding NL, Jung HY, Mickus T, Spruston N. Dendritic calcium spike initiation and repolarization are controlled by distinct potassium channel subtypes in CA1 pyramidal neurons. J Neurosci. 1999;19(20):8789-98.

14. Granados-Soto V, Arguelles CF, Ortiz MI. The peripheral antinociceptive effect of resveratrol is associated with activation of potassium channels. Neuropharmacology. 2002;43(5):917-23.

15. Guerrini R, Dravet C, Genton P, Belmonte A, Kaminska A, Dulac O. Lamotrigine and seizure aggravation in severe myoclonic epilepsy. Epilepsia. 1998;39(5):508-12.

16. Gupta YK, Briyal S, Chaudhary G. Protective effect of trans-resveratrol against kainic acid-induced seizures and oxidative stress in rats. Pharmacol Biochem Behav. 2002;71(1-2):245-9.

17. Hebert B, Pietropaolo S, Meme S, Laudier B, Laugeray A, Doisne N, Quartier A., Lefeuvre S, Got L, Cahard D, Laumonnier F, Crusio WE, Pichon J, Menuet A, Perche $\mathrm{O}$, Briault $\mathrm{S}$. Rescue of fragile $\mathrm{X}$ syndrome phenotypes in Fmr1 $\mathrm{KO}$ mice by a BKCa channel opener molecule. Orphanet J Rare Dis. 2014;9:124.

18. Heredia A, Davis C, Redfield R. Synergistic inhibition of HIV-1 in activated and resting peripheral blood mononuclear cells, monocyte-derived macrophages, and selected drug-resistant isolates with nucleoside analogues combined with a natural product, resveratrol. J Acquir Immune Defic Syndr. 2000;25(3):246-55.

19. Heron SE, Crossland KM, Andermann E, Phillips HA, Hall AJ, Bleasel A, Shevell M., Mercho S, Seni MH, Guiot MC, Mulley JC, Berkovic SF Scheffer IE. Sodium-channel defects in benign familial neonatal-infantile seizures. Lancet. 2002;360(9336):851-2.

20. Jakab M, Lach S, Bacova Z, Langeluddecke C, Strbak V, Schmidt S, Iglseder E, Paulmichl M, Geibel J. Ritter M. Resveratrol inhibits electrical activity and insulin release from insulinoma cells by block of voltage-gated $\mathrm{Ca}+$ channels and swelling-dependent $\mathrm{Cl}$ - currents. Cell Physiol Biochem. 2008;22(5-6):567-78.

21. Kim HI, Kim $\mathrm{TH}$, Song JH. Resveratrol inhibits $\mathrm{Na}+$ currents in rat dorsal root ganglion neurons. Brain Res. 2005;1045(1-2):134-41.

22. Lee HY, Jan LY. Fragile $X$ syndrome: mechanistic insights and therapeutic avenues regarding the role of potassium channels. Curr Opin Neurobiol. 2012;22(5):887-94 
23. Lee JG, Yon JM, Lin C, Jung AY, Jung KY, Nam SY. Combined treatment with capsaicin and resveratrol enhances neuroprotection against glutamateinduced toxicity in mouse cerebral cortical neurons. Food Chem Toxicol. 2012;50(11):3877-85.

24. Li HF, Chen SA, Wu SN. Evidence for the stimulatory effect of resveratrol on $\mathrm{Ca}(2+)$-activated $\mathrm{K}+$ current in vascular endothelial cells. Cardiovasc Res. 2000;45(4):1035-45.

25. Li M, Wang QS, Chen Y, Wang ZM, Liu Z, Guo SM. Resveratrol inhibits neuronal discharges in rat hippocampal CA1 area. Acta Physiologica Sinica. 2005;57(3):355-60

26. Li M, Wang QS, Chen Y, Wang ZM, Liu Z, Guo SM. Resveratrol inhibits the electrical activity of subfornical organ neurons in rat. Acta Physiologica Sinica. 2005;57(4):523-8.

27. Li YQ, Li ZL, Zhao WJ, Wen RX, Meng QW, Zeng Y. Synthesis of stilbene derivatives with inhibition of SARS coronavirus replication. Eur J Med Chem. 2006;41(9):1084-9.

28. Lofrumento DD, Nicolardi G, Cianciulli A, De Nuccio F, La Pesa V, Carofiglio V, Dragone T, Calvello R, Panaro MA. Neuroprotective effects of resveratrol in an MPTP mouse model of Parkinson's-like disease: possible role of SOCS-1 in reducing pro-inflammatory responses. Innate Immun. 2014;20(3):249-60.

29. Mantegazza M, Curia G, Biagini G, Ragsdale DS, Avoli M. Voltage-gated sodium channels as therapeutic targets in epilepsy and other neurological disorders. Lancet Neurol. 2010;9(4):413-24.

30. Meftahi G, Ghotbedin Z, Eslamizade MJ, Hosseinmardi N, Janahmadi M. Suppressive effects of resveratrol treatment on the intrinsic evoked excitability of CA1 pyramidal neurons. Cell journal. 2015;17(3):532-9.

31. Meng XJ, Wang F, Li CK. Resveratrol is neuroprotective and improves cognition in pentylenetetrazole-kindling model of epilepsy in rats. Indian J Pharm Sci. 2014;76(2):125-31.

32. Mokni M, Hamlaoui S, Karkouch I, Amri M, Marzouki L, Limam F, Aouani E. Resveratrol provides cardioprotection after ischemia/ reperfusion injury via modulation of antioxidant enzyme activities. Iran J Pharm Res. 2013;12(4):867-75

33. Movahed A, Yu L, Thandapilly SJ, Louis XL, Netticadan T. Resveratrol protects adult cardiomyocytes against oxidative stress mediated cell injury. Arch Biochem Biophys. 2012;527(2):74-80.

34. N'Gouemo P. BKCa channel dysfunction in neurological diseases. Front Physiol. 2014;5:373.

35. N'Gouemo P. Targeting BK, (big potassium) channels in epilepsy. Expert Opin Ther Targets. 2011:15(11):1283-95.

36. Ohbuchi T, Yokoyama T, Fujihara H, Suzuki H, Ueta Y. Electrophysiological identification of the functional presynaptic nerve terminals on an isolated single vasopressin neurone of the rat supraoptic nucleus. J Neuroendocrinol. 2010;22(5):413-9.

37. Penumathsa SV, Thirunavukkarasu M, Koneru S, Juhasz B, Zhan L, Pant R, Menon VP, Otani H, Maulik N. Statin and resveratrol in combination induces cardioprotection against myocardial infarction in hypercholesterolemic rat. J Mol Cell Cardiol. 2007:42(3):508-16.

38. Perez GJ, Desai M, Anderson S, Scornik FS. Large-conductance calciumactivated potassium current modulates excitability in isolated canine intracardiac neurons. Am J Physiol Cell Physiol. 2013;304(3):C280-6.

39. Rogawski MA, Loscher W. The neurobiology of antiepileptic drugs for the treatment of nonepileptic conditions. Nat Med. 2004;10(7):685-92.

40. Saha L, Chakrabarti A. Understanding the anti-kindling role and its mechanism of Resveratrol in Pentylenetetrazole induced-kindling in a rat model. Pharmacol Biochem Behav. 2014;120:57-64.

41. Shen KZ, Lagrutta A, Davies NW, Standen NB, Adelman JP, North RA. Tetraethylammonium block of slowpoke calcium-activated potassium channels expressed in xenopus-oocytes - evidence for tetrameric channel formation. Pflugers Arch - Eur J Physiol. 1994;426(5):440-5.

42. Shetty AK. Promise of resveratrol for easing status epilepticus and epilepsy. Pharmacol Ther. 2011;131(3):269-86

43. Thuc LC, Teshima Y, Takahashi N, Nishio S, Fukui A, Kume O, Saito S, Nakagawa M, Saikawa T. Inhibition of $\mathrm{Na}(+)-\mathrm{H}(+)$ exchange as a mechanism of rapid cardioprotection by resveratrol. Br J Pharmacol. 2012;166(6):1745-55.

44. Torres-Lopez JE, Ortiz MI, Castaneda-Hernandez G, Alonso-Lopez R, Asomoza-Espinosa R, Granados-Soto V. Comparison of the antinociceptive effect of celecoxib, diclofenac and resveratrol in the formalin test. Life Sci. 2002;70(14):1669-76
45. van Giersbergen PL, Treiber A, Clozel M, Bodin F, Dingemanse J. In vivo and in vitro studies exploring the pharmacokinetic interaction between bosentan, a dual endothelin receptor antagonist, and glyburide. Clin Pharmacol Ther. 2002;71(4):253-62.

46. Virgili M, Contestabile A. Partial neuroprotection of in vivo excitotoxic brain damage by chronic administration of the red wine antioxidant agent, transresveratrol in rats. Neurosci Lett. 2000;281(2-3):123-6.

47. Wallace $\mathrm{CH}$, Baczko I, Jones L, Fercho M, Light PE. Inhibition of cardiac voltage-gated sodium channels by grape polyphenols. Br J Pharmacol. 2006;149(6):657-65

48. Wang Q, Xu J, Rottinghaus GE, Simonyi A, Lubahn D, Sun GY, Sun AY. Resveratrol protects against global cerebral ischemic injury in gerbils. Brain Res. 2002:958(2):439-47.

49. Wang Q, Yu S, Simonyi A, Rottinghaus G, Sun GY, Sun AY. Resveratrol protects against neurotoxicity induced by kainic acid. Neurochem Res. 2004 29(11):2105-12.

50. Wang R, Xiao L, Ma HJ, Zhang LH, He RR, Wu YM. Resveratrol inhibits electrical activity of paraventricular nucleus neurons in rat hypothalamic slices. Acta Physiologica Sinica. 2008;60(2):279-83.

51. Wang YJ, Lin MW, Wu SN, Sung RJ. The activation by estrogen receptor agonists of the BK(Ca)-channel in human cardiac fibroblasts. Biochem Pharmacol. 2007;73(9):1347-57.

52. Wang YJ, Liu YC, Chang HD, Wu SN. Diosgenin, a plant-derived sapogenin, stimulates $\mathrm{Ca} 2+-$ activated $\mathrm{K}+$ current in human cortical HCN-1A neuronal cells. Planta Med. 2006;72(5):430-6.

53. Wood JN, Boorman JP, Okuse K, Baker MD. Voltage-gated sodium channels and pain pathways. J Neurobiol. 2004;61(1):55-71.

54. Wu Z, Xu Q, Zhang L, Kong D, Ma R, Wang L. Protective effect of resveratrol against kainate-induced temporal lobe epilepsy in rats. Neurochem Res. 2009;34(8):1393-400.

55. Yan L, Wang Q, Fu Q, Ye Q, Xiao H, Wan Q. Amitriptyline inhibits currents and decreases the mRNA expression of voltage-gated sodium channels in cultured rat cortical neurons. Brain Res. 2010;1336:1-9.

56. Zhang XF, Gopalakrishnan M, Shieh CC. Modulation of action potential firing by iberiotoxin and NS1619 in rat dorsal root ganglion neurons. Neuroscience. 2003;122(4):1003-11.

\section{Submit your next manuscript to BioMed Central and we will help you at every step:}

- We accept pre-submission inquiries

- Our selector tool helps you to find the most relevant journal

- We provide round the clock customer support

- Convenient online submission

- Thorough peer review

- Inclusion in PubMed and all major indexing services

- Maximum visibility for your research

Submit your manuscript at www.biomedcentral.com/submit 